\title{
Є.I. Гоник
}

\section{ОСОБЛИВОСТІ ФОРМУВАННЯ ФІТОМАСИ ВУГІЛЬНОГО ПЛАСТА $n_{8}$ ШАХТИ № 4 «ВЕЛИКОМОСТІВСЬКА» ЛЬВІВСЬКО-ВОЛИНСЬКОГО БАСЕЙНУ ЗА ПАЛІНОЛОГІЧНИМИ ДАНИМИ}

\section{E.I. Gonyk \\ THE PECULIARITIES OF PHYTOMASS FORMATION OF THE $n_{8}$ COAL BED FROM THE MINE NO. 4 VELYKOMOSTIVSKA OF THE LVIV-VOLYN BASIN BY THE PALYNOLOGICAL DATA}

Дослідження дисперсної органічної речовини вугілля пласта $n_{8}$ шахти № 4 «Великомостівська» Львівського-Волинського басейну методом паліноориктоценозів виконані уперше. Визначено склад дисперсної органіки, систематичний склад міоспор, виділено різні типи паліноориктоценозів та визначені особливості їх розподілу в розрізі пласта. Встановлено склад палеорослинності і визначено фрази формування фітомаси палеоторфовища вугільного пласта $n_{8}$.

Ключові слова: паліноориктоценоз, дисперсна органічна речовина, спори, Львівсько-Волинський басейн.

Изучение дисперсного органического вещества угольного пласта $n_{8}$ шахты № 4 «Великомостовская» Львовско-Волынского бассейна методом палиноориктоценозов проведено впервые. Определен состав дисперсной органики, систематический состав спор, выделены разные типы палиноориктоценозов и выяснены особенности их распределения в разрезе пласта. Установлены состав палеорастительности и фразы фрормирования палеоторфяника угольного пласта $n_{8}$.

Ключевые слова: палиноориктоценоз, дисперсное органическое вещество, споры, Львовско-Волынский бассейн.

Investigations of dispersed organic matter of coal bed $n_{8}$ from the mine No. 4 «Velykomostivska» of the LvivVolyn basin by method of palynoorictocenosis made for the first time. The composition of dispersed organic matter and systematic composition of spores were studied. It was determined different types of palynoorictocenosis and clarified peculiarities of its distribution in the section of coal bed. By palynogical data it is defined paleovegetation and picked out forming phases of coal peat bog of coal bed $n_{8}$.

Key words: palynoorictocenosis, dispersed organic matter, spores, Lviv-Volyn basin.

\section{ВСТУП}

Львівсько-Волинський кам'яновугільний басейн - це важлива паливно-енергетична база Західної України. Продуктивними в басейні $€$ кам'яновугільні відклади, що представлені візейським і серпуховським ярусами нижнього відділу і башкирським ярусом середнього відділу та утворюють вугленосну формацію. У вугленосній фрормації басейну визначено 98 вугільних пластів і прошарків вугілля, з яких 30 - робочої потужності (0,6 м). Одним із основних промислових пластів басейну є вугільний пласт $n_{8}$. Він залягає у відкладах бужанської світи. В межах басейну даний пласт має майже повсюдне латеральне поширення та інтенсивно розробляється нововолинськими та великомостівськими шахтами, причому зберігає робочу потужність 0,6-2,3 м (за переважних значень 1,0-1,2 м) на значній площі розвитку. Загальна площа розвитку пласта досягає 820 км². Однак внаслідок розмивів і заміщень вугілля фактична площа його поширення ледь сягає 720 км².

Флористичні залишки є головним компонентом вугільних пластів. Склад рослинних решток впливає на якість вугілля, його фізико-хімічні властивості і шляхи використання в тих чи інших галузях народного господарства. Вивчення складу решток є необхідним для проведення детальної стратифікації і кореляції вугленосних розрізів, палеогеографічних і палеокліматичних реконструкцій. Палінологічне вивчення вугленосної формації Львівсько-Волинського басейну проводилось А.М. Іщенко, І.І. Партикою, О.Г. Шварцман, А.В. Іваніною. Ці дослідники вивчали переважно вуглевмісні товщі, а вугільні пласти при цьому залишалися поза їхньою увагою. 
Головна мета палінологічного вивчення вугленосної фрормації басейну на даному етапі така: дослідження залежності особливостей поховань мікроскопічних рослинних залишків від палеогеографічних умов, визначення головних вуглетворних рослинних асоціацій, виділення паліноориктоценозів за складом і співвідношеннями мікрокомпонентів, з'ясування особливостей розподілу паліноориктоценозів у розрізі та умов формування вугільних пластів.

\section{МАТЕРІАЛИ ТА МЕТОДИ}

Метод паліноориктоценозів розроблений у 90-х роках XX ст. А.В. Іваніною [3]. Під терміном «паліноориктоценоз» розуміють викопне угруповання найдрібніших частинок органіки. Цей метод передбачає вивчення всієї дисперсної органіки осадових порід для отримання комплексної інформації про вік, стратиграфрічне положення та генезис товщ, визначення типу дисперсної органіки 3 метою реконструкції палеорослинності, коректних біостратиграфічних висновків і визначення перспектив нафртогазо- і вугленосності відкладів [1].

На сучасному етапі досліджень методом паліноориктоценозів вивчено розріз пласта $n_{8}$ у шахті № 4 «Великомостівська». Здійснено детальний пошаровий відбір зразків (майже через кожні 1,5-2,0 см) з цього пласта.

3 отриманих мацератів виготовляли тимчасові або постійні препарати, які вивчали під мікроскопом. Мікроскопічне вивчення об‘єктів здійснювалося на біологічних мікроскопах «Біополам» та «Axiolab» при збільшенні у 200-600 разів, і супроводжувалося фотографуванням мацерату та окремих родів і видів міоспор. Загалом, було вивчено 27 постійних препаратів, відібраних з розрізу вугільного пласта $n_{8}$ шахти № 4 «Великомостівська».

Дослідження дисперсної органічної речовини (ДОР) проводили за методикою, викладеною у роботах А.В. Іваніни та ін. $[2,3]$. Для отримання палінологічної характеристики кожного зразка фріксували таке: видовий і родовий склад міоспор; загальну кількість і вміст окремих родів і видів; ступінь насиченості мацерату міоспорами (іï оцінку проводять за загально прийнятою градацією: багато - підрахунок виконаний з одного скла до 200 екз. і більше, помірно - від 50 до 200 зерен на скло, мало - підрахунок обмежений 50 формами); колір - за семибальною шкалою, розробленою Л.В. Ровніною [7]; ступінь збереженості визначали згідно з методичними рекомендаціями.

У зв'язку з великим обсягом фрактичного матеріалу і за відсутністю єдиної схеми класифрікації виникли труднощі в питаннях систематизації і визначення міоспор. За основу прийнята фрормальна морфологічна класифікація Р. Потоньє і Г. Кремпа, яка в наш час широко застосовується в країнах Західної Європи. Використовували також схему уніфрікованої класиффікації міоспор палеозою А.А. Любер, прогресивний момент якої - виділення таксонів крупного рангу за різним характером будови апертури. Крім того, застосовували таксономічні одиниці, запропоновані деякими дослідниками - В.К. Тетерюком, Т.В. Бившевою. Як порівняльний матеріал використовували вітчизняну і зарубіжну літературу, серед якої, варто відмітити роботи В.К. Тетерюка, К.І. Іносової, А.Х. Крузіної, О.Г. Шварцман по Донецькому басейну $[5,6]$. Визначення міоспор через значне різноманіття і політаксонність матеріалу проводили переважно до родів.

Під час палінологічного дослідження вугільного пласта $n_{8}$ визначено понад 35 родів міоспор. За кількісними співвідношеннями до спор-домінант належать роди Densosporites (вміст у спектрах коливається від 70 до 95\%) і Lycospora (від 20 до 60\%). Серед субдомінант (від 5 до 40\%) визначено близько шести-восьми родів, зокрема Cingulizonates, Leiotriletes, Granulatisporites, Acanthotriletes. Більша частина спор належить до рідкісних 5\% (20-25 родів): Punctatisporites, Vestispora, Triquitrites, Convolutispora, Dictyotriletes та ін. (puc. 1).

У розрізі вугілля шахти № 4 «Великомостівська» спостерігається домінування плауноподібних рослин. Тут головну вуглетворну роль відіграють селагінели, кількість яких становить у прошарку гумусового вугілля близько $70 \%$, а по всьому вугільному пласту до 80-90\%. Другорядну роль відіграють лепідодендрони, папороті, меншою мірою - членистостеблові.

За співвідношеннями компонентів ДОР та за спорами-домінантами в розрізах вугільного пласта $n_{8}$ шахти № 4 «Великомостівська» визначено три типи паліноориктоценозів: лікоспоровий, денсоспоровий та змішаний. 


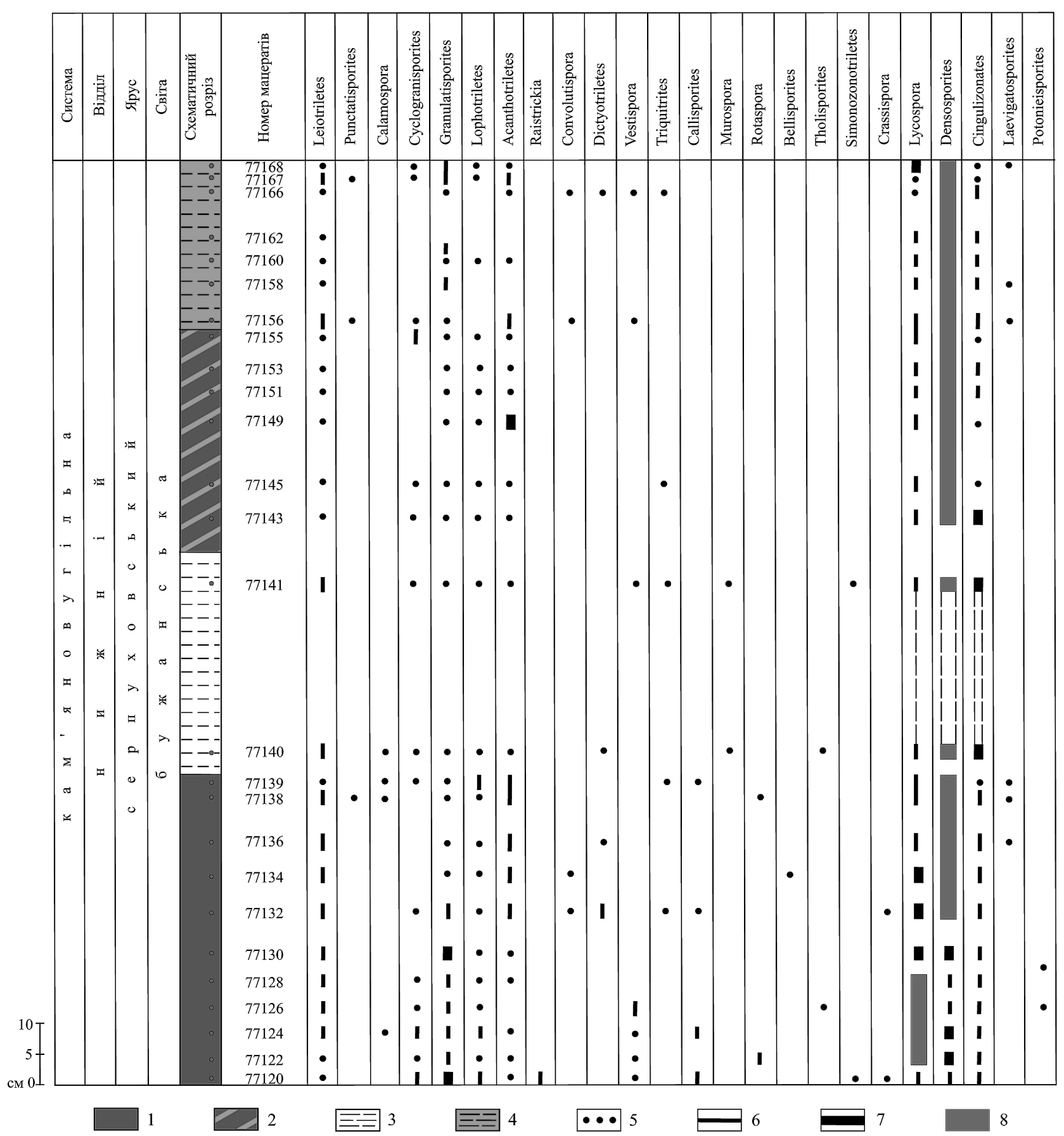

Рис. 1. Схема поширення головних родів міоспор та пилку у вугільному пласті $n_{8}$ шахти № 4 Великомостівська Львівсько-Волинського басейну: 1 - гумусове вугілля; 2 - сапропелево-гумусове вугілля; 3 - аргіліт; 4 - сапропелітовий аргіліт. Кількість спор і пилку: 5 - спорадично і поодинокі; 6 - до 10 \%; 7 - 10-20 \%; 8 - найхарактерніше поширення

Характеристика паліноориктоценозів наведена у роботі, присвяченій умовам фрормування вугільного пласта $n_{8}$ [2].

\section{РЕЗУЛЬТАТИ ТА ЇХ ОБГОВОРЕННЯ}

Пласт $n_{8}$ розрізу шахти № 4 «Великомостівська» (товщина $150 \mathrm{~cm}$ ) характеризується складною будовою - в ньому виділено пачку гумусового (товщина 50 см) і пачку сапропелітово-гумусового (38 см) вугілля, що поділені аргілітовим прошарком (35 см).

Вертикальний розподіл паліноориктоценозів у розрізі вугільного пласта нерівномірний. Так, знизу вверх виділена така вертикальна послідовність паліноориктоценозів:

1. У прошарку гумусового вугілля:

- Змішаний тип паліноориктоценозу (товщина близько 3 см). Характеризується малою 
насиченістю ліптинітової речовини, а також домінуванням міоспор папоротей (77\%). Тут є роди Callisporites, Granulatisporites, Leiotriletes, Cyclogranisporites, Raistrickia. Міоспори плауноподібних становлять близько $20 \%$ спектра. Меншою мірою зустрічаються міоспори ботродендронів (Crassispora), пилок (Schulzospora). Тип ДОР належить до гумусового, з переважанням уламків вітреніту.

- Лікоспоровий тип паліноориктоценозу (товщина близько $18 \mathrm{~cm}$ ). Вміст міоспор деревоподібних плауноподібних коливається від 50 до 70\%. 3 міоспор селагінел переважають Cingulizonates над Densosporites, загальна кількість яких у сумі досягає 20$38 \%$. Серед папоротей значно розповсюджені роди Granulatisporites, Leiotriletes, меншою мірою Cyclogranisporites, Lophotriletes, Callisporites. Каламіти (Calamospora), клинолисткові (Vestispora), пилок (Schulzospora, Potonieisporites) поодинокі. Серед інших елементів ліптинітової речовини присутня помірна кількість трахеїд, меншою мірою кутикули. ДОР головним чином представлена гумусовою складовою, 3 домінуванням вітреніту і помірною кількістю інертініту.

- Змішаний тип паліноориктоценозу (товщина близько $3 \mathrm{~cm}$ ). Характерним для цього типу $є$ переважання міоспор плауноподібних рослин з домінуванням міоспор селагінел. Загальний обсяг міоспор плауновидних становить 90\%. Серед спор папоротей (10\%) домінують роди Granulatisporites, Leiotriletes. $€$ поодинокі фрагменти трахеїд. Тип ДОР гумусовий (домінування вітреніту).

- Денсоспоровий тип паліноориктоценозу (товщина близько $25 \mathrm{~cm}$ ). Вміст Densosporites у даному типі паліноориктоценозі поступово зростає вверх за розрізом і становить від 42 до 92\%. Міоспори лепідодендронів присутні у кількості 2-25\%. Крім того, значне розповсюдження отримали Cingulizonates (2-12\%), папороті Acanthotriletes (2-10\%), Granulatisporites, Leiotriletes, Convolutispora, Triquitrites (до $1 \%)$, клинолисткові (Laevigatosporites).

2. Породний прошарок (аргіліт) з денсоспоровим типом паліноориктоценозу (товщина близько $35 \mathrm{~cm}$ ).

3. Сапропелітово-гумусове вугілля з денсоспоровим типом паліноориктоценозу (товщина близько 38 см). Характеризується доволі бідним родовим складом. Вміст міоспор родів Lycospora (1-10\%), Cingulizonates (до
5\%), Acanthotriletes (2-12\%). Інші міоспори Cyclogranisporites, Triquitrites є поодинокими.

4. Породний прошарок сапропелітового аргіліту 3 денсоспоровим типом паліноориктоценозу (товщина $27 \mathrm{~cm}$ ).

Тобто відбувається зміна: у гумусовому вугіллі - Z (товщина прошарку, в якому визначені змішані палінориктоценози, 3 cм), L (18 см), Z (3 см), D (25 см); породний прошарок (товщина $35 \mathrm{~cm}$ ) і сапропелітово-гумусове вугілля з денсоспоровим типом.

Серед компонентів ДОР для розрізу вугільного пласта шахти № 4 «Великомостівська» характерне переважання елементів гумусової групи, зокрема вітреніту. Інші компоненти - фррагменти кутикул і трахеїд - мало поширені у препаратах і $є$ лише в гумусовому типі вугілля.

А.X.В. Смітт [8] встановив умови формування кам'яновугільних торфовищ вугільного басейну в Англії за палінологічними даними. За аналогією, дотримуючись його моделі, у формуванні вугільного пласта $n_{8}$ Львівсько-Волинського басейну можна виділити такі фрази: лікоспорову, денсоспорову та проміжну. Лікоспорова фраза відповідає класичному уявленню про торф'яні болота. В цей час існувала переважно деревоподібна рослинність, над торфом був тонкий шар води, і розкладання рослинної речовини відбувалося в анаеробних умовах. Денсоспорова фаза відповідає торфам, поверхня яких знаходилася вище рівня води в умовах високої вологості атмосфери. Проміжна фраза, яка йде за лікоспоровою, відповідає прогресивному обмілінню води. Коли ж вона змінює денсоспорову, то тоді, навпаки, відповідає поступовому заглибленню.

Виходячи з викладеного, на початку формування палеоторфовища вугільного пласта $n_{8}$ накопичення фітомаси відбувалося в умовах сильно обводненого середовища. В цей час серед рослин домінували деревоподібні плауноподібні. Пізніше відбувалося обміління води і наступала досить тривала денсоспорова фраза, що відповідала торфам, поверхня яких знаходилася вище рівня води, та коли розкладалася переважно трав'яниста рослинність. Накопичення сапропелітово-гумусового вугілля продовжувалося в умовах обводненого торф'яного болота з розкладанням рослинних залишків в анаеробних умовах (рис. 2). 


\section{€.I. гоник}

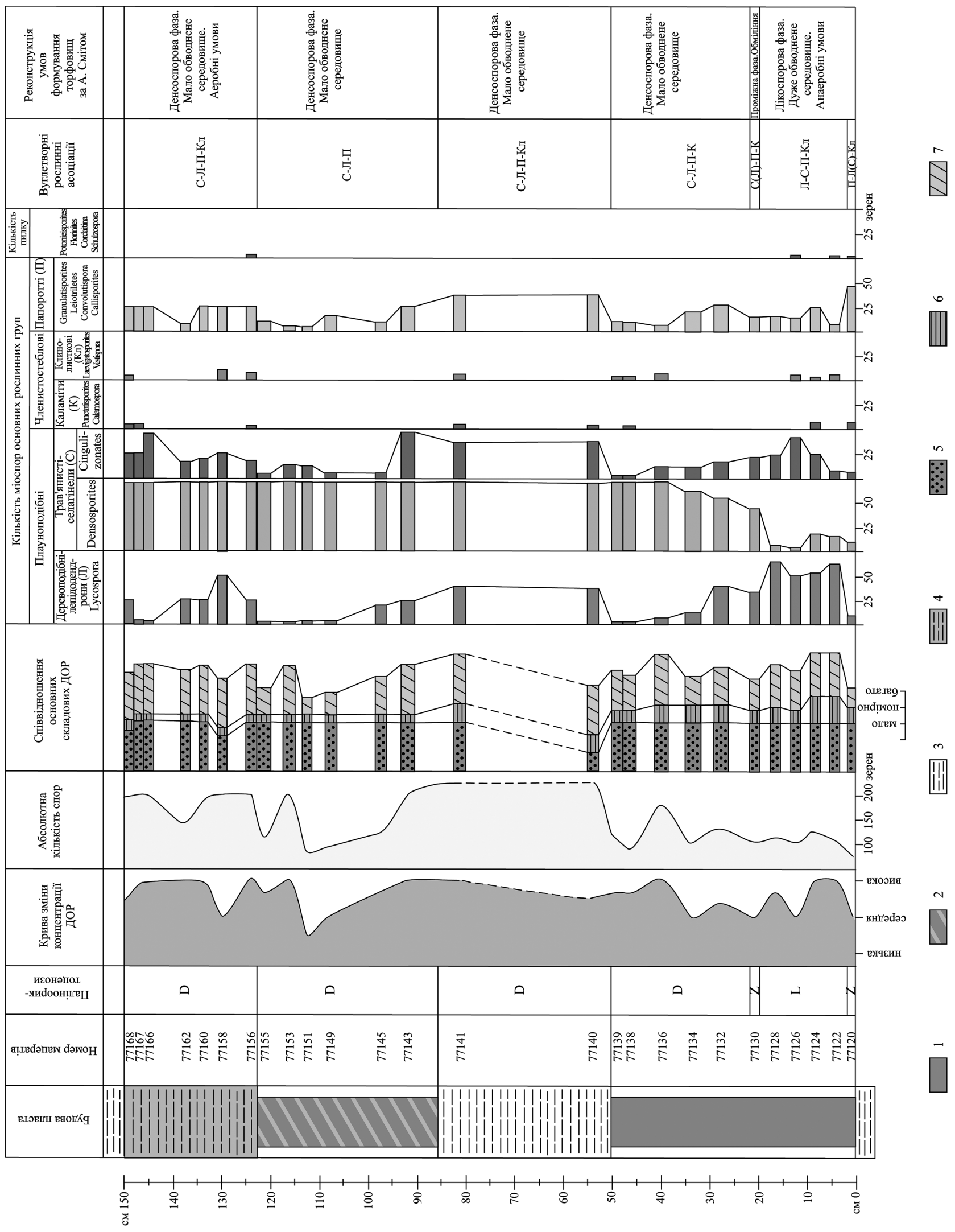

Рис. 2. Схема фаз формування та складу дисперсної органіки вугільного пласта $n_{8}$ шахти № 4 Великомостівська Львівсько-Волинського басейну: 1 - гумусове вугілля; 2 - сапропелево-гумусове вугілля; 3 - аргіліт; 4 - сапропелітовий аргіліт. Складові дисперсної органічної речовини: 5 - елементи гумусової групи; елементи ліптинітової групи: 6 - кутикули, трахеїди; 7 - міоспори 


\section{ВИСНОВКИ}

Отже, пошарове палінологічне вивчення вугільного пласта $n_{8}$ шахти № 4 «Великомостівська» Львівсько-Волинського басейну дало змогу виявити закономірне чергування в розрізі паліноориктоценозів, відновити фрази формування (денсоспорова, проміжна, лікоспорова) та на цій підставі реконструювати умови утворення вугільного пласта (обміління-обводнення).

1. Іваніна А.В. Новий підхід до вивчення палінологічних решток древніх осадочних товщ // Геологогеофізичні дослідження нафтогазоносних надр України. - Львів: УкрДГРІ, 1997-1998. - С. 129135.

2. Іваніна А., Гоник $€$. Умови фрормування вугільного пласта $n_{8}$ шахти № 1 Нововолинська ЛьвівськоВолинського басейну за палінологічними даними // Вісн. Львів. ун-ту. Сер. геол. - 2010. - Вип. 24. - С. 171-182.

3. Іваніна А.В., Шульга В.Ф. Фаціальнопалінологічний аналіз вугленосної формації Львівсько-Волинського басейну // Геол. журн. 1996. - № 3-4. - С. 108-114.
4. Иванина А.В., Шульга В.Ф. Фациальнопалинологическое изучение угленосных отложений (на примере Львовско-Волынского бассейна) // Бюл. Моск. о-ва испытателей природы. Отд. геол. - 2005. - Т. 80, вып. 5. - С. 36-42.

5. Иносова К.И., Крузина А.Х., Шварцман Е.Г. Атлас микроспор и пыльцы верхнего карбона и нижней перми Донецкого бассейна. - М.: Недра, 1976. $176 \mathrm{c}$.

6. Крузина А.Х., Узиюк В.И., Швариман Е.Г. Палинолого-петрографические исследования для детального расчленения и корреляции угольных пластов Донбасса // Сов. геология. - 1984. № 12. - C. 53-62.

7. Ровнина Л.В. Рассеяное нерастворимое органическое вещество или кероген // Методические аспекты палинологии. - М.: Недра, 1987. - С. 185194.

8. Смит А.Х.В. Условия формирования каменноугольных торфяников // Реконструкция климатов по ископаемым углям. - М.: Мир, 1968. C. 52-61.

Львівський національний університет імені Івана Франка, Львів

E-mail: evgonik@bk.ru 